\title{
Developing a modular apparel safety architecture for supply chain management: the apparel recycle perspective
}

\author{
DOI: 10.35530/IT.069.01.1380
}

LIHONG CHEN

HONG YU

XINFENG YAN

\section{REZUMAT - ABSTRACT}

Dezvoltarea unei arhitecturi modulare în ceea ce privește siguranța îmbrăcămintei pentru managementul lanțului de aprovizionare

Această lucrare prezintă o problemă specială referitoare la opțiunile strategice pentru implementarea îmbrăcămintei reciclabile. O implementare substanțială privată este necesară în cazul în care trebuie să se atingă obiectivele de management ale întreprinderii cu scopul de a crește cota de îmbrăcăminte reciclabilă și de a preveni riscul de producere a îmbrăcămintei nocive. Scopul acestei lucrări și întreaga abordare este de a atrage atenția asupra proceselor care stau la baza alegerilor strategice pentru implementarea îmbrăcămintei reciclabile. S-a elaborat și implementat un cadru de arhitectură modulară pentru siguranța îmbrăcămintei (MASA) pentru managementul lanțului de aprovizionare cu scopul de a oferi orientări pentru designerii și producătorii de îmbrăcăminte pentru ca aceștia să rezolve problemele de siguranță și durabilitate legate de producția de îmbrăcăminte. Cadrul MASA a fost dezvoltat prin integrarea unei teorii modulare și a conceptului de produs reciclabil în designul și producția existentă a îmbrăcămintei. Designul și producția de îmbrăcăminte pentru copii au fost utilizate pentru a pune în aplicare cadrul MASA ca un concept real. Cadrul MASA este primul model de design și producție a îmbrăcămintei care subliniază siguranța și reciclabilitatea, în plus față de considerentele funcționale, expresive și estetice. Originalitatea acestei lucrări este capacitatea acesteia de a combina aspectele sociale, tehnice, de mediu și economice utilizând o teorie modulară cu scopul de a oferi un punct de vedere holistic asupra factorilor care influențează sistemul de îmbrăcăminte reciclabil prin proiectarea și dezvoltarea modulelor de management reciclabil.

Cuvinte-cheie: siguranța îmbrăcămintei, sistem de îmbrăcăminte reciclabilă, design modular, managementul lanțului de aprovizionare

\section{Developing a modular apparel safety architecture for supply chain management: the apparel recycle perspective}

This paper introduces the special issue on strategic choices for recyclable clothing implementation. Substantial private implementation is needed if company management objectives to increase the share of recyclable clothing and prevent dangerous clothing risk be achieved. The aim of this paper, and the entire special issue, is to draw scholarly attention to the processes underlying strategic choices for recyclable clothing implementation. An modular apparel safety architecture (MASA) framework for supply chain management was developed and implemented to provide guidelines for apparel designers and manufactures to solve safe and sustainable problems related to apparel production. The MASA framework was developed by integrating modular theory and product recyclable concept into existing apparel design and production. Children's clothing design and production was used to implement the MASA framework as a proof concept. The MASA framework is the first apparel design and production model that emphasizes safety and recyclability in addition to functional, expressive, and aesthetic considerations. The originality of this work is its ability to combine social, technical, environmental and economic aspects using modular theory in order to provide a more holistic point of view on factors impacting recyclable clothing system through the design and development of recyclable management modules.

Keywords: apparel safety, recyclable apparel system, modular design, supply chain management

\section{INTRODUCTION}

The limited reserves and negative environmental impacts associate with fossil fuel consumption make the recyclable clothing considerable alternatives in case environmental externalities and sustainability are taken into consideration [1]. In addition, increasing use of recyclable clothing is a vital importance in mitigating increasing resource shortage and waste clothing to accomplish sustainable development. Recyclable clothing is becoming increasingly important for recycling economies in many countries. But still in an emerging industry, recyclable clothing requires supportive management policy helping firms to develop and protect competitive advantages in global competition. Apparel recycling is also a major energy-saving and environment-friendly strategic emerging industry in the world, and a prioritized management strategy for apparel recycling should be established for the maximum apparel recycling.

A detailed understanding of apparel safety and apparel recycle in the textile industry is critical for fair and equitable apparel supply chain management policies. This study adds new perspective on the role 
of textile process innovation for reducing the risks of textile sector. In the literature on apparel safety and recycle, important headway has been made in understanding the factors that drive apparel safety and apparel recycle strategies, such as apparel safety sources and recall activities [2-3]. However, less attention has been paid to the determinants of the adoption of recyclable safety apparel supply chain management that aim to reduce the apparel risk, recycle costs and add reuse value. Such management strategies include the sourcing of apparel raw material, design or production that result in the decomposition of the apparel for recycling.

This article has proposed an integration of design for disassembly into the modularization framework and apparel supply chain to measure apparel safety and recycles. Policy-makers can use those insights for designing policy that supports recyclable clothing implement with a scope on customer safety needs rather than technology or price. Additionally, we state important implications for recyclable clothing entrepreneurs, managers and research, and therefore, such a research is of interest for entrepreneurs and managers for understanding how to adjust their initiatives with the apparel safety's requirements and thus increasing the likeliness of recycling success.

\section{BACKGROUND AND ORGANIZATION OF THE PAPER}

The paper describes recyclable clothing system, an integrated modular approach for maximizing safety, recyclability, performance, ecological efficiency and profitability in the textile industry. The fundamental principles of integrated recyclable clothing system provide a global roadmap to a recyclable economy based on the closed loop supply chain. The purpose of this paper is to develop and implement a kind of modular apparel safety architecture (MASA) framework for supply chain management, which provides guidelines for apparel designers and manufactures to solve safe and sustainable problems related to apparel production. The MASA framework was developed by an integration of design for disassembly into the modularization framework and closed loop apparel supply chain to measure apparel safety and recycles. Children's clothing design and production was used to implement the MASA framework as a proof concept.

The originality of this work is its ability to combine safety, technological and environmental aspects using modularity theory in order to provide a more holistic point of view on factors impacting closed loop apparel supply chain. This study adds new perspective on the role of textile process innovation for reducing the risks of textile sector. We intend to contribute in several areas: we provide insight on recyclable clothing companies' strategic implementation framework. They have implications for management policy and may serve as indicator for designing effective implementation plan that fosters competitiveness of recyclable clothing firms and contributes to further dif- fusion of recyclable clothing. Further, entrepreneurs and managers may utilize the results for formulating corporate strategies and designing business management models. A peripheral contribution is to research on decision-making in sustainable supply chain management. Our work enhances the concept of closed loop apparel supply chain by contributing explorative evidence on the value of different green management components from a managements' point of view.

We proceed as follows: in the next section we briefly discuss apparel safety and closed loop supply chain. The featured understanding of apparel safety serves as the basis for the module design later on. Then, we discuss aspects of apparels to characterize business managers for recyclable clothing in general and to better understand whom we asked. In the module section, we elaborate on the safe-based conjoined modular units. We then present our results and explore modular apparel safety architecture framework and state propositions from managerial and operational levels. Based on the stated framework, we model generic recyclable implementation modules for children's clothing. We wrap up by drawing conclusions and pointing to potential implications for clothing policy and for recyclable clothing entrepreneurial and managerial practice and research.

\section{LITERATURE REVIEW}

\section{Apparel safety}

Apparel safety becomes higher qualifying 'ticket' for the product to enter the market. In fact, quite a number of technical regulations and standards to consider apparel safety have developed and the market becomes more sophisticated, which aims to see that apparel must meet requirements of the safety test in various countries. An objective analysis of user safety needs uncovered through technical regulations/ standards and recall cases led to the development of apparel safety categories and indicator inventories [4]. The evaluation method of apparel safety has been studied over the years. Wu conducted a safety risk evaluation model for textile and apparel by the method of BP neural network that has been proved in a step-by-step way using practical inspection data [5]. A risk assessment model integrating the SVM technology was developed for measuring the textile and apparel safety [6]. Zhou studied the potential mechanical hazards of children's clothing by the method of fault tree [7]. Pang further conducted risk assessment for textile and apparel by the application of TS fuzzy neural network [8]. The design of ecological textile messages was presented to use environmental-friendly technology and raw materials in textile product design for reducing toxic chemical substances in children's clothing [9]. On the whole, apparel safety management is obviously important in apparel reuse and recycle. Effective reuse and recycle of textile and apparel requires an accurate prediction of the quality of textile and apparel parts 
generated. However, the recycle and reuse incorporating safety in apparel supply chain management is not well structured. Specifically, it is not clear how apparel safety management is related to apparel recycle and reuse.

\section{Apparel recycle and reuse}

According to Gam and Cao, cradle to cradle apparel design is a new sustainable apparel design and production model, which emphasizes sustainability and recyclability in apparel supply chain [1]. The application of design for disassembly methods in men's jacket design and construction were conducted to show a design for recycle or reuse different materials and components at the end of the jacket's usable life [10]. Pattern transformation were applied in clothing and tent design and experimentally demonstrated that outdoor clothing and tent with similar application occasions and raw materials, which could realize recycle and reuse design goal by wearing and assembling [11]. The technical experiment for clothing style change were conducted by the transformation design of clothing structure elements to enable raw materials for one garment to could be reused for two or more garments [12]. Textile waste recycling and sustainable development were studied to achieving environmental sustainability [13].

Textiles are a largely untapped consumer commodity with a strong reuse and recycling potential as well as reducing environmental burden [14], which was investigated in a case study on consumers' clothing disposal behaviours [15]. For encouraging consumer behavior with more awareness of the sustainable clothing, the design of sustainable clothing should be normalized and the interventions should be adopted for upcycling, recycling and repair [16]. For reuse and recycling of textile products, the companies' strategies can adopt the uses of environmental friendly materials or apparel reuse [17]. Lack of technology, lack of material to recycle and lack of consumer awareness are the most important barriers to recycling apparel and apparel manufacturers should be encouraged to develop marketing strategies to ensure recycle more extensively [18].

\section{Product modularization for parts reuse}

Product modularization for parts reuse is a very effective method to apply the concept of reuse rather than the conventional material recycling [19]. Modular product concept selection was also applied to choose the best design for subsequent development with least risk to the enterprise [20]. Modular design was used in the assembly and disassembly of product components to support green life-cycle engineering [21]. Modular design can facilitate life-cycle material efficiency through component material reuse and such material reuse modularity must conform to the technical system modularity [22]. Modular design was combined with design for environment concept to reduce the potential negative environmental impacts as early as at the design stage of products. Design for assembly and design for recyclability were regarded as some specific methods for design for environment methodologies [23]. In this paper, design for disassembly and design for recyclability concept needs to be highlighted in apparel design for recyclability.

With the above situation as background, the objective of this paper is to propose a new method for apparel design and product structure modularization that rationalizes the reuse/recycle activities, and to show a new possibility for designing apparels with better reuse potential. Furthermore, a modular architecture framework of safety conscious decision support is proposed for apparel design and production. According to this framework, safety concern can be taken into consideration as early as at the stages of apparels; and based on the result of the analysis, the potential negative impact of safety on the apparel reuse and recycle can be maximally reduced.

A conceptual model of strategic choices for recyclable clothing system

\section{Starting point: practical implement process of SDPRAD model}

The MASA framework was practically implemented in four main steps: safety problem definition and research; product solution development and collaboration; recycling value creation and other recovery. In step (1), all apparel safety indicators found to be potential harmful to wearers were combined to determine which apparel attributes would be selected for prevention in the final recyclable clothing system. As an intermediate step (2), apparel attributes were modularized decomposition in clothing design and production for potential reuse based on product solution development and collaboration in clothing recycling system. The point to be stressed is that improvement should be prioritized to maximize safe control in the whole design and recycle triangle. In step (3), the recycling value creation process was implemented through turning apparel attributes into another apparel or other value product. In the last step (4), recovered clothing was disposed with some value recovery including secondary use after technical treatments. This conducting process could be illustrated in figure 1.

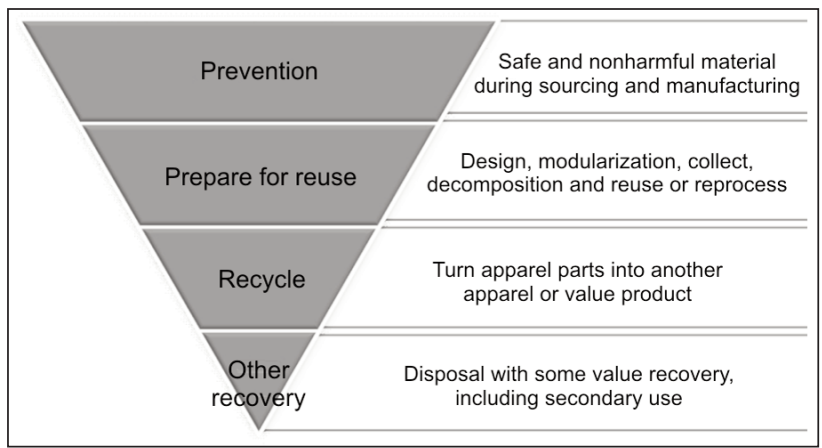

Fig. 1. The practical implement process for MASA framework 


\section{Modular apparel safety architecture framework}

Based on the literature review on apparel safety, apparel recycle/reuse and product modularization for reuse, we developed a modular apparel safety architecture framework (figure 2) as a lens to supervise apparel safety.

In our modular apparel safety architecture framework shown in figure 2, we decompose modular safety architecture into two levels: managerial and operational. The managerial-level decisions provide the guidelines for the apparel safety management and recycle, and integration of the operational-level business activities (figure 3). Next, we discuss the managerial and operational levels of our modular apparel safety architecture framework in more detail.

At the managerial level, we identify the supply chain management components in keeping with apparel safety attributes in integration of apparel recycle. These components describe the context in which enterprises introduce safety modularity and the guidelines for their business processes. The principles for sourcing, design, production, modularization and recycle guide the design, raw materials sourcing, processing, delivery and recycle technologies at the operational level. Next, we briefly interpret these principles with regard to apparel safety in our framework context.

The supply chain management components at the managerial level of the modular apparel safety architecture framework (figure 2) entail sourcing, design,



Fig. 2. MASA framework

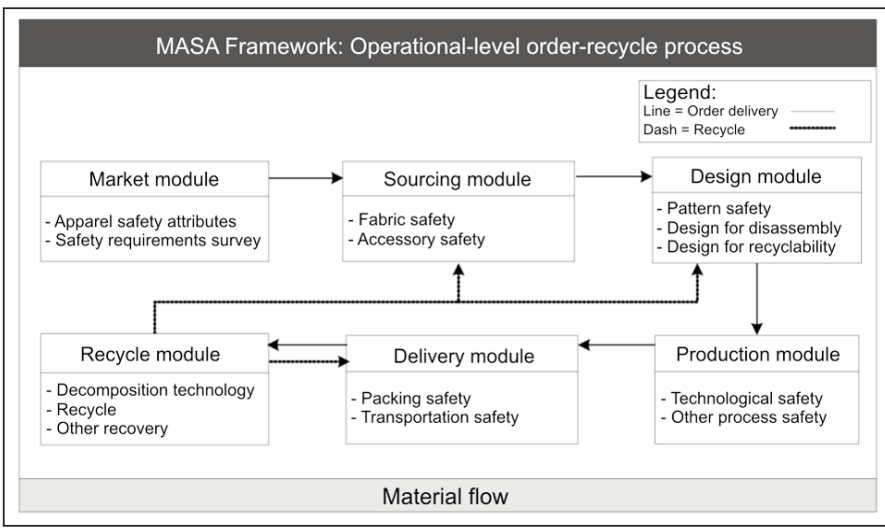

Fig. 3. Decomposing the operational level of apparel's order-recycle process production, modularization and recycle principles to implement a safe apparel order-recycle process. Sourcing principles include decisions on fabric safety and accessory safety. A multitude of fabric and accessory safety needs to be taken to account in the supply chain design to be able to offer safe raw materials for all target customers. At the core of a supply chain management of recyclable apparel system are design and production principles, which should provide the comprehensive and detailed apparel safety attributes management for conducting a material flow necessary for operating apparel recycle. The modularization principles decompose the apparel safety attributes into the order-recycle process, each of which can be further divided down to the basic procedures or recycle procedures. The recycle principles disassemble apparel into the lowest-level parts that can be define as various kinds of fabrics, lining, buttons and other accessories.

Based on the managerial-level decisions on sourcing, design, production, modularization and recycle principles in figure 2 , the resulting operational-level business activities provide more fine and specific contents of implementation to ensure apparel safety and recycle. The operational level of the modular apparel safety architecture framework is depicted in figure 3 . The operational-level order-recycle process comprises six lower-level key modules - market, sourcing, design, production, delivery and recycle and then further consists of the lowest-level components within each module.

The market module conducts a survey on apparel safety requirements in term of customers and their attributes in apparel. The sourcing module offers different sourcing options for fabrics and accessories. The design module is part of both the front-end apparel safety subprocess and the back-end apparel recycle subprocess internal to the firm. On the front end, the firm can confirm the design and material regarding the apparel safety and the apparel disassembly. The production module consists of technological safety management, including stonewashed jeans, breakage of thread and so on. Other process safety includes broken needles, scissors and other instruments that have potential risk to customers. The delivery module organizes its packing and transportation submodule in the delivery procedure. The recycle module's one option provide solutions for the customers for return the apparel, and the other option offer alternatives for the customers for not returning the apparel. The returned apparel limits the decomposition solutions to the apparel. The recycle subprocess flow is delineated by a dashed line in figure 3.

In short, a safe apparel order-recycle fulfillment process requires the integration of apparel safety requirements, design, production, delivery and recycles strategies. Next, we apply our modular apparel safety architecture framework to analyze the order-recycle processes for the case study children's clothing. 


\section{Case descriptions}

In this interpretive case study, we apply our modular apparel safety architecture framework shown in figure 2 and figure 3 to assist in the children's clothing design and production process. Our objective is to analyze the children's clothing orderrecycle process and summarize step by step the procedures, modules and safety attributes found at different operational level as well as their classification by procedure type into material, design, production and recycle options. The apparel safety information flows related to the order-recycle process are the focus of this paper, so we discuss them at length in the case descriptions.

A detailed summary of all procedures, modules, and safety attributes found in the case children's clothing order-recycle processes is available in figure 4 (by procedures) and table 1 (by Children's clothing safety attributes).
Modular children's clothing safety architecture: Operational-level order-recycle process

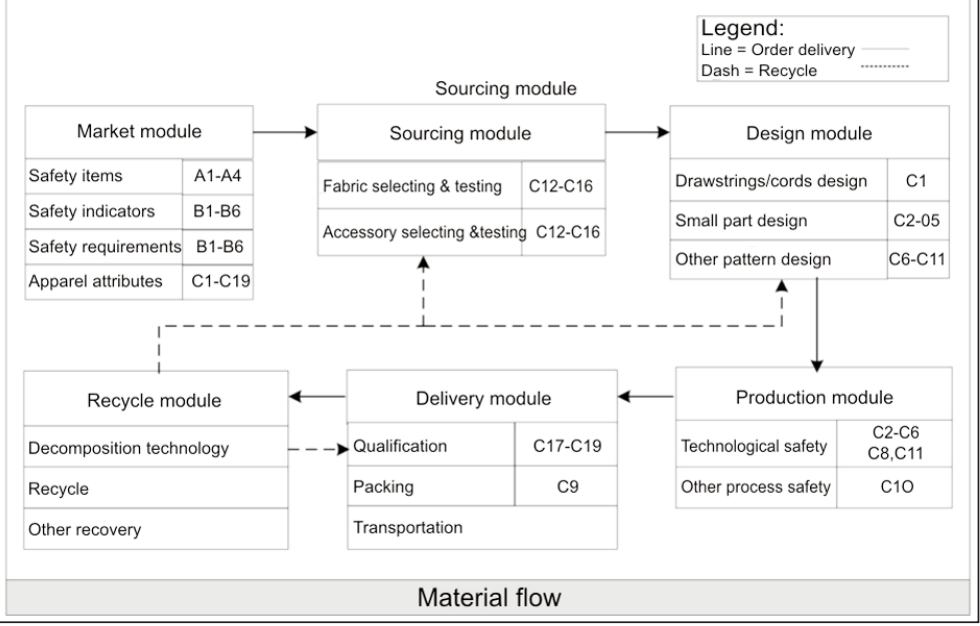

Fig. 4 Children's clothing order-recycle process: Operational Level Procedures and Submodules

In the market module, children's clothing safety demands and a wide of variety of children's clothing

\begin{tabular}{|c|c|c|}
\hline \multicolumn{3}{|c|}{ CHILDREN'S CLOTHING SAFETY INDICATORS AND THEIR ATTRIBUTES [4] } \\
\hline Items & Indicators & Children's clothing safety attributes \\
\hline \multirow[t]{3}{*}{$\begin{array}{l}\text { (A1) } \\
\text { Mechanical } \\
\text { Safety }\end{array}$} & $\begin{array}{l}\text { (B1) The length and use requirements of } \\
\text { drawstrings/cords }\end{array}$ & $\begin{array}{l}\text { (C1) drawstring, functional or decorative cord, elastic } \\
\text { cord, shoulder strap, halter neck cord, tied belt or } \\
\text { sash, stirrup and loop in children's garments }\end{array}$ \\
\hline & $\begin{array}{l}\text { (B2) The size, intensity, abrasion resistance } \\
\text { of small parts }\end{array}$ & $\begin{array}{l}\text { (C2) buttons, snaps and knots } \\
\text { (C3) zipper sliders, zipper pullers, pull tabs, rings and } \\
\text { toggles at the end of drawstrings } \\
\text { (C4) decorative small parts: pom-poms, appliqué, } \\
\text { heated patch, crochet tassel, small pieces of } \\
\text { fabric in the hem of clothing, spangles and beads } \\
\text { (C5) touch and close fastener, fringe, bows, feather, } \\
\text { label, badge, tabs }\end{array}$ \\
\hline & (B3) The use requirements of other parts & $\begin{array}{l}\text { (C6) hood, filling materials, sharp objects, neckties, } \\
\text { garment with integral feet, magnetic material and } \\
\text { embroidery } \\
\text { (C7) The dimension of open } \\
\text { (C8) Intensity and abrasion resistance of sewing thread } \\
\text { (C9) Materials and thickness of package bags } \\
\text { (C10) The instruments used in manufacture like } \\
\text { needles, sharp weapons(e.g. scissors), stone } \\
\text { washing or metal detection process } \\
\text { (C11) Seam security, seam strength, binding security } \\
\text { of snap, unrepaired thread end or floating }\end{array}$ \\
\hline $\begin{array}{l}\text { (A2) } \\
\text { Chemical } \\
\text { Safety }\end{array}$ & $\begin{array}{l}\text { (B4) Formaldehyde content, color fastness } \\
\text { to water, Acid color fastness to } \\
\text { perspiration, Alkali color fastness to } \\
\text { perspiration, Color fastness to dry } \\
\text { friction resistance, Color fastness to } \\
\text { saliva resistance, pH value, Abnormal } \\
\text { taste, AZO Dye }\end{array}$ & $\begin{array}{l}\text { (C12) fabrics: knots, bows, pom-poms, appliqué, } \\
\text { heated patch, crochet tassel, small pieces of } \\
\text { fabric and so on } \\
\text { (C13) buttons, fasteners, embroidery, zippers, spangles } \\
\text { and beads } \\
\text { (C14) sewing thread }\end{array}$ \\
\hline $\begin{array}{l}\text { (A3) } \\
\text { Flammable } \\
\text { Safety }\end{array}$ & (B5) Flammability requirements & $\begin{array}{l}\text { (C15) fabrics } \\
\text { (C16) padding }\end{array}$ \\
\hline $\begin{array}{l}\text { (A4) } \\
\text { External Safety }\end{array}$ & (B6) Qualification requirements & $\begin{array}{l}\text { (C17) qualification of product identification } \\
\text { (C18) fiber composition in label/tag } \\
\text { (C19) washing and nursing label }\end{array}$ \\
\hline
\end{tabular}


safety attributes are available through investigation and study on market research as well as related safety technical regulations and standards. Most of attributes come from raw materials or design process, while production and delivery procedure have safety attributes as well. These attributes exist in mechanical safety, chemical safety, flammable safety and external safety (table 1) [4]. The mechanical safety addressed the safety of drawstrings/cords, small parts and other possible sources in children's clothing. The chemical safety consists of residual poisonous and harmful substances in fabrics and supplementary material. The flammable safety is defined as failing no meet the flammable standards for fabrics or padding in children's clothing. The external safety means that qualification and authenticity of label/tag instructions in children's clothing.

Based on the survey and research results in market module, sourcing module and design module can be conducted immediately and must meet corresponding safety requirements that are available in the safety indicator inventory. In current industrial divisions, most apparel manufactures purchase fabrics or accessories from other industries or suppliers. To assist with prioritization of industry or company choices based on safety in their product offerings, an assessment of fabrics or accessories can be an insightful starting point and enable meaningful strategies for apparel manufacturer specializing chemical safety and flammable safety of materials. On top of this, it should be used in a safe pattern design for children's clothing, such as drawstrings/cords and small parts design, which is a major source of mechanical safety in children's clothing.

In production module, there are two kinds of safety management arouse attention, technological safety (i.e., intensity of small parts, abrasion resistance of sewing thread, seam security, seam strength, binding security of snap, unrepaired thread end or floating) and other process safety from instruments used in production process.

The delivery module includes labeling, packing, warehousing and transporting submodules. Labels/ tags (i.e., fiber composition, washing/nursing label) are attached to children's clothing are required authenticity and qualification. Packaging material testing and packaging form selecting require special attention and knowledge, such as thickness of package bags for suspension packaging or flat folding package.

The recycle module is very easy and flexible as well. Apparel can be returned to firms or apparel recycling bodies via various channels instructed in advance. Then, apparel returned is decomposed into various fabrics (i.e., cotton, polyester, hemp, wool and blended fabrics) and accessories (i.e., buttons, zippers, snaps, fasteners, labels, and ornaments) for further use in another sourcing module and design module. Another is worth mentioning, apparel returned can also be used as second-hand clothing.

\section{CONCLUSIONS AND FUTURE RESEARCH}

The MASA framework hopes to raise awareness about apparel choices and support safe designs and productions, environmentally preferable recycle and reuse. The MASA framework aims to change the way apparel are made, by providing that it's possible to produce safe, environmental apparels in ways that are safe, economic and sustainable. The devised MASA framework incorporates safety technical risks arising from involvement of textile and apparel with components, thus addressing the risk mitigation method for design concept selection from an enterprise point of view. Incorporating safety indicators of specific modules based on their contribution towards textile recycle and reuse is an important extension of this research. It is expected that the results of this work would be helpful for further research in understanding the dynamics behind recycle mechanism of the clothing in different environments. A possible future direction of research would be to incorporate specific aspects such as disassembly and recycle of textile and apparel in the existing formulation. The major benefits associated with the MASA framework are: assessing safety to support the effective exploration and penetration of recyclable clothing and reducing the risk of end products. There are barriers for further development of the recyclable clothing in China. The Chinese government plays a critical role to remove these barriers.

\section{ACKNOWLEDGEMENTS}

We thank China Postdoctoral Science Foundation (2014M561387) and Shanghai University of Engineering Science Foundation (2016-25) for providing the financial support to complete this work.

\section{BIBLIOGRAPHY}

[1] Gam, H.J., Cao, H.T., Farr, C., Heine, L. C2CAD: a sustainable apparel design and production model, In: International Journal of Clothing Science and Technology, 2009, vol. 21, no. 4, pp. 166-179.

[2] Chen L., Ding X., Wu X. Comparison of mechanical safety requirements and test methods of children's garments in Chinese and Euramerican standards, In: International Conference on Textile Bioengineering and Informatics Symposium, Shanghai, China, 28-30 May 2010.

[3] Chen, L., Wu, X., Ding, X. The definition of the defect for textiles and apparel defect in recall in China, In: International Conference on Advanced Textile Materials \& Manufacturing Technology, Hangzhou, China, 15-19 October 2008.

[4] Chen, L.H., Yan, X.F., Gao, C.C. Developing a practical evaluation framework for identifying critical factors to achieve apparel safety, In: The Journal of The Textile Institute, 2016, vol. 107, no. 12, pp. 1519-1532. 
[5] Wu, X.Y., Chen, L.H., Zhou, Y., Ding, X.M. Research in risk assessment for textile and apparel and propose a future research agenda with a conceptual framework, In: International Journal of Productivity and Quality Management, 2016, vol.17, no. 3, pp. 273-288.

[6] Wu, X.Y., Chen, L.H., Pang, S.H., Ding, X.M. Paratactic subjective-objective weighting methods and SVM risk assessment model applied in textile and apparel safety, In: International Journal of Quality \& Reliability Management, 2015, vol. 32, no. 5, pp. 472-485.

[7] Zhou, Y., Wu, X., Chen, L., Ding, X. Analysis of potential mechanical hazards of children's clothing based on fault tree method, In: International Conference on Textile Bioengineering and Informatics Symposium, Shanghai, China, 28-30 May 2010.

[8] Pang, S., Zhou Y., Ding X., Wu X. Application of TS fuzzy neural network in safety risk assessment of textile and apparel, In: Fuzzy Systems and Knowledge Discovery (FSKD) of Eighth International Conference, Shanghai, China, 26-28 July 2011.

[9] Taieb, A.H., Hammami, M., Msahli, S. , Sakli, F. Sensitising children to ecological issues through textile eco-design, In: International Journal of Art \& Design Education, 2010, vol. 29, no. 3, pp. 313-320.

[10] Gam, H.J., Cao, H.T., Farr, C., Bennett, J., Helmkamp, C., Farr, C. Application of design for disassembly in men's jacket: A study on sustainable apparel design, In: International Journal of Clothing Science and Technology, 2011, vol. 23, no. 2-3, pp. 83-94.

[11] Wang, W.Z., Wang, Y., Yu, S.L., Sun, L., Liu, J., Wei, X.M. Design for mutual transformation between outdoor wear and camping tent, In: International Journal of Clothing Science and Technology, 2014, vol. 26, no. 4, pp. $291-304$.

[12] Wang, W.Z., Yu, S.L., Wang, Q.Z., Luan, Y.B., Wang, J.Z., Wang, L.H., Guo, C.J. Study on eco-clothing with multiple style transformation in the background of cyclic economy, In: 4th International Conference on Manufacturing Science and Engineering, Dalian, China, 30-31 May 2013.

[13] Cuc, S., Iordanescu, M., Girneata, A., Irinel, M., "Environmental and socioeconomic sustainability through textile recycling", In: Industria Textila, 2015 , vol. 66, no. 3, pp. 156-163.

[14] Zurga, Z., Hladnik, A., Tavcer, P.F. Environmentally sustainable apparel acquisition and disposal behaviours among Slovenian consumers, In: Autex Research Journal, 2015, vol. 15, no. 4, pp. 243-259.

[15] Laitala, K. Consumers' clothing disposal behavior - a synthesis of research results, In: International Journal of Consumer Studies, 2014, vol. 38, no. 5, pp. 444-457.

[16] Harris, F., Roby, H., Dibb, S.Sustainable clothing: challenges, barriers and interventions for encouraging more sustainable consumer behavior, In: International Journal of Consumer Studies, 2016, vol. 40, no. 3, pp. 309-318.

[17] $\mathrm{Na}$, Y., Na, D.K. (2015), Investigating the sustainability of the Korean textile and fashion industry. In: International Journal of Clothing Science and Technology, vol. 27, no. 1, pp. 23-33.

[18] Larney, M., van Aardt, A.M. Case study: Apparel industry waste management: a focus on recycling in South Africa, In: Waste Management and Research, 2010, vol. 28, no. 1, pp. 36-43.

[19] Kimura, F., Kato, S., Hata, T., Masuda, T. Product modularization for parts reuse in inverse manufacturing, In: CIRP Annals - Manufacturing Technology, 2001, vol. 20, no. 1, pp. 89-92.

[20] Goswami, M., Tiwari, M.K. A predictive risk evaluation framework for modular product concept selection in new product design environment, In: Journal of Engineering Design, 2014, vol. 25, no. 1-3, pp. 150-171.

[21] Tseng, H.E., Chang, C.C., Li, J.D. Modular design to support green life-cycle engineering, In: Expert System with Applications, 2008, vol. 34, no. 4, pp. 2524-2537.

[22] Ji, Y.J., Jiao, R.J., Chen, L., Wu, C.L. Green modular design for material efficiency: a leader follower joint optimization model, In: Journal of Cleaner Production, 2013, vol. 41, pp. 187-201.

[23] Qian, X., Zhang, H. Design for environment: An environmental analysis model for the modular design of products, In: $11^{\text {th }}$ International Symposium on Electronics and the Environment/4 $4^{\text {th }}$ Electronics Recycling Summit, Boston, US, 19 May - 22 May 2010.

\section{Authors: \\ LIHONG CHEN ${ }^{1}$ \\ HONG YU2 \\ XINFENG YAN ${ }^{3}$ \\ Shanghai University of Engineering Science \\ ${ }^{1}$ School of Fashion Engineering, Department of Fashion Design and Engineering \\ 2 Shanghai Institute of Quality Inspection and Technical Research \\ 3 International Cultural Exchange School, Department of Business and Management \\ 333 Long Teng Road, 201620 \\ Shanghai, China \\ e-mail: Ihckxyy@163.com,79067192@qq.com, yanxf@dhu.edu.cn}

Corresponding author:

LIHONG CHEN

e-mail: Ihckxyy@163.com 